American Journal of Agricultural and Biological Sciences 5 (1): 32-36, 2010

ISSN 1557-4989

(C) 2010 Science Publications

\title{
Characterization of Substrate-Borne Vibrational Signals of Euschistus servus (Heteroptera: Pentatomidae)
}

\author{
${ }^{1}$ Brittany Lampson, ${ }^{1}$ Young Han, ${ }^{1}$ Ahmad Khalilian, ${ }^{2}$ Jeremy Greene, \\ ${ }^{3}$ R.W. Mankin and ${ }^{3}$ Everett Foreman \\ ${ }^{1}$ Department of Biosystems Engineering, Clemson University, \\ Clemson, SC 29634 \\ ${ }^{2}$ Department of Entomology, Soils and Plant Sciences, Clemson University, \\ Clemson, SC 29634 \\ ${ }^{3}$ United States Department of Agriculture-Agricultural Research Service, Center for Medical, Agricultural \\ and Veterinary Entomology, \\ 1600 Southwest 23rd Drive, Gainesville, FL 32608
}

\begin{abstract}
Problem statement: Stink bugs were not major pests of cotton in the southeastern United States until cotton varieties containing Bacillus thuringiensis (Bt) transgenes came into common use, enabling reductions in insecticide applications against highly destructive lepidopteran pests. To maintain the benefits of reduced insecticide applications, it would be advantageous to detect and target isolated populations of stink bugs before they rise to economically important levels. However, detection methods for these pests are less than optimal, and alternative methods are being investigated. One novel method of detection would be to exploit substrate-borne vibrational signals of these bugs.

Approach: To develop an effective vibration detection method, substrate-borne vibrational signals produced by different species commonly occurring in the region must be characterized sufficiently to enable detection of these species in the absence of visual observation. In this research, substrateborne vibrational signals were recorded from the brown stink bug Euschistus servus. These signals were categorized by dominant frequency, duration, and repetition time using a Gaussian mixture model, revealing an assortment of "songs" in an acoustic repertoire. Results: Females of E. servus emitted two distinct songs while males of E. servus emitted four distinct songs. Results indicated that the repertoire of this species differs from that of other species in the same geographical location (southeastern United States) reported in previous literature. Conclusion/Recommendations: In conclusion, detection of pentatomid pests by their substrate-borne vibrational signals must include the parameters of each unique song of each species of stink bug to be detected, including those of the two female and four male songs of E. servus. The characterization of these songs will allow for the development of a monitoring system in the field using strategically placed accelerometers to detect stink bug vibrational communication and thus provide a density map of the location of these pests.
\end{abstract}

Key words: Brown stink bug, vibrational communication

\section{INTRODUCTION}

Widespread adoption of cotton, Gossypium hirsutum (L.), containing transgenes from bacterium Bacillus thuringiensis (Bt) has resulted in significant reductions in foliar-applied insecticides for major lepidopteran pests of the crop. However, with less pesticide use, species of stink bugs that previously would have been controlled coincidentally by applications of insecticides are causing economic damage to cotton (Roach, 1988; Turnipseed and Greene, 1996; Greene et al., 2001). Stink bugs feed on developing seeds in young bolls, causing bolls or individual locks to become hardened, discolored and unharvestable (Wene and Sheets, 1964; Barbour et al., 1988). Prior to 1996, there were few or no reports of losses and control costs associated with stink bugs in cotton in the US. In 2005 alone, losses due to stink bugs were estimated to be over $\$ 63$ million in the US, with control costs exceeding $\$ 11.5$ million (Williams, 2006).

Corresponding Author: Brittany Lampson, Department of Agricultural and Biological Engineering, Clemson University, 221 McAdams Hall, Clemson, SC 29634 Tel: 864-656-4082 Fax: 864-656-0338 
In order to preserve the benefits of $B t$ cotton, detection methods are recommended for stink bugs that provide some measure of pest density or damage, allowing targeted control with insecticides. Because these detection methods are far less than optimal, additional strategies for detecting stink bugs are under investigation. One such novel method of detection would be to exploit the substrate-borne vibrational signals of these bugs.

Vibrational signals mediate intraspecific communication among individuals of many species of stink bugs including Nezara viridula (L.) (Harris et al., 1982), Acrosternum hilare (Say) (Cokl et al., 2001) and Euschistus servus (Say), important pentatomidae pest species in the southeastern United States (Roach, 1988; Bundy and McPherson, 2000). Stink bugs use vibrational signals in both medium-range location (calling) and short-range recognition (courtship) of mates in which each "song" corresponds and is specific to different stages in the mating process (Cokl and Virant-Doberlet, 2003). The spectra of the vibrational signals frequently are tuned to the low-frequency structural resonances of host plant twigs and branches (Cokl, 2008). Although the characteristics of these songs have been intensively investigated in many species of stink bugs including E. conspersus (McBrien and Millar, 2003) and E. heros (Blassioli Moraes et al., 2005), two species in the same genus as $E$. servus, no literature exists on the vibratory communications of E. servus, the brown stink bug. The goal of this research was to determine temporal and spectral characteristics of pulses and pulse trains of the various songs emitted from E. servus.

\section{MATERIALS AND METHODS}

Collection and rearing of insects: Over 100 adults of E. servus were used for this experiment, including some reared from eggs from mated females in the laboratory and some collected from fields of cotton and soybeans at the Edisto Research and Education Center near Blackville, South Carolina, in late spring and early summer of 2008. Stink bugs were reared and/or held in multiple plastic cages and fed a diet of fresh green beans and raw peanuts (Harris and Todd, 1981). The cages were held in a controlled environment room at $30^{\circ} \mathrm{C}$ and $70 \%$ relative humidity with a photoperiod of 14:10 (L:D) h.

Rearing and use of plants: Three cotton, Gossypium hirsutum (L.), plants of variety DP 164 B2RF (Delta and Pine Land 164 Bollgard 2 RoundupReady Flex) planted in plastic black pots $27.94 \mathrm{~cm}$ in diameter and $24.13 \mathrm{~cm}$ tall at the Edisto Research and Education Center near Blackville, South Carolina, during April 2008 were used in the experiments. The plants varied in height from 0.6-0.9 $\mathrm{m}$ and were blooming and setting bolls during experimentation.

Recording vibrational signals: All recordings were made from 23-26 June 2008 with sexually mature bugs between 0900 and $2100 \mathrm{~h}$ in an anechoic chamber located at the USDA Center for Medical, Agricultural and Veterinary Entomology in Gainesville, Florida. Signals were recorded using accelerometers (Model 4370, Brüel and Kjær, Naerum, Denmark) attached to the cotton plant by alligator clips at 14 and $55 \mathrm{~cm}$ above the soil. This setup was enclosed in a $0.6 \times 0.6 \times 1.2 \mathrm{~m}$ wire mesh cage to contain the bugs. After setup, various numbers of stink bugs were placed inside the cage on the plant near the accelerometers. To identify a range of different signals produced by males and females, ten recordings of $90 \mathrm{~s}$ each were made of 10 males only, 10 females only and 1 male-female pair and thirty recordings of $90 \mathrm{~s}$ each were made of various numbers of males and females numbering 30 total stink bugs. Signals were amplified $20 \mathrm{~dB}$ using a charge amplifier (Model 2635, Brüel and Kjær, Naerum, Denmark) and $30 \mathrm{~dB}$ using a secondary amplifier (Model 2610, Bruel and Kjær, Naerum, Denmark) and then bandpassfiltered between 70 and $2,000 \mathrm{~Hz}$ before being digitized at $44.1 \mathrm{kHz}$ using a speech analysis system (model 4300B, Kay Elemetrics Corp., Lincoln Park, NJ).

Data analysis: Spectral and temporal characteristics of the songs were determined from the digitized recordings. A pulse was defined as a discrete unit within a series of similar units, a pulse train as a group of pulses with a characteristic sequence or form, a song as a group of pulse trains of the same type and repetition time as the time interval between the start of two sequential signals or particular pulses (Cokl et al., 2001). Signals were analyzed using oscilloscope software (Multi-Instrument Lite 3.0, Virtins Technology, Singapore, Singapore) and dominant frequencies, durations and repetition times were calculated from the recordings. Dominant frequency (frequency of maximum energy) was determined using the Fast Fourier Transform function and duration and repetition times for each pulse train were calculated by averaging the duration of each pulse and the repetition times between pulses in the pulse train.

To discriminate male from female songs, data from the males only cage was first fit to a Gaussian Mixture Model (GMM) using MATLAB functions gmdistribution.fit and cluster (MATLAB 7, Mathworks 
Inc., Natick, MA). Subsequently, data from females only in the cage also was fit to a GMM using MATLAB. Remaining songs were classified as one of the previously identified male or female songs using a GMM, and mean dominant frequency, duration and repetition time were used to verify classifications.

Analysis of variance followed by the Games-Howell multiple comparison procedure was used to compare mean dominant frequency, duration and repetition time of each classification. Analysis of variance followed by either Student's t test for equal variances or Welch's $t$ test for unequal variances was performed to compare mean duration and repetition time of each song of $E$. servus to songs of $N$. viridula from Florida (Cokl et al., 2000). Test statistics were calculated using the published means, standard deviations and sample sizes for the narrow-band female calling song, the broadband female calling song, the narrow-band male calling song, the broad-band male calling song, the male courtship song and the male rivalry song. A significance level of 0.05 was used in all analyses.

\section{RESULTS}

Characteristic pulse trains for female and male $E$. servus signals were revealed in oscillograms that defined four distinct songs for males (Fig. 1) and two distinct songs for females (Fig. 2). Female songs were designated as F1 and F2 while the male songs were designated as M1-4. These classifications were also verified by the relationship of frequency to duration and repetition time for male (Fig. 3) and female (Fig. 4) songs.

Analysis of variance showed variances of dominant frequency $(\mathrm{F}=321.64 ; \mathrm{df}=5,525 ; \mathrm{p}<0.001)$, duration $(\mathrm{F}=153.12 ; \mathrm{df}=5,525 ; \mathrm{p}<0.001)$ and repetition time $(\mathrm{F}=956.51 ; \mathrm{df}=5,525 ; \mathrm{p}<0.001)$ were significantly different among songs and the Games-Howell multiple comparison procedure showed significant differences among means of the dominant frequency, duration and repetition time of various songs (Table 1). Results obtained are presented as means and standard deviations and the number of pulse trains analyzed is shown.

Songs classified as F2 and M3 were often recorded as a duet with the songs alternating. The average time elapsed between the end of F2 and the beginning of M3 was $4.253 \pm 3.924 \mathrm{~s}(\mathrm{~N}=18)$ and the average time elapsed between the end of M3 and the beginning of F2 was $2.327 \pm 3.339 \mathrm{~s}(\mathrm{~N}=10)$.

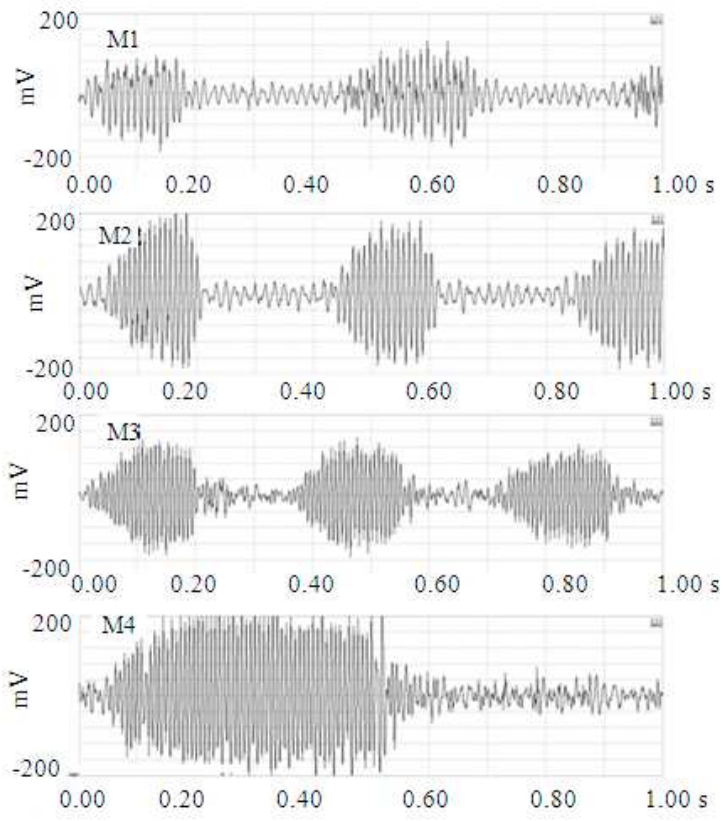

Fig. 1: Sample oscillograms of pulse trains for substrate-borne songs of Males (M1-4) of E. servus

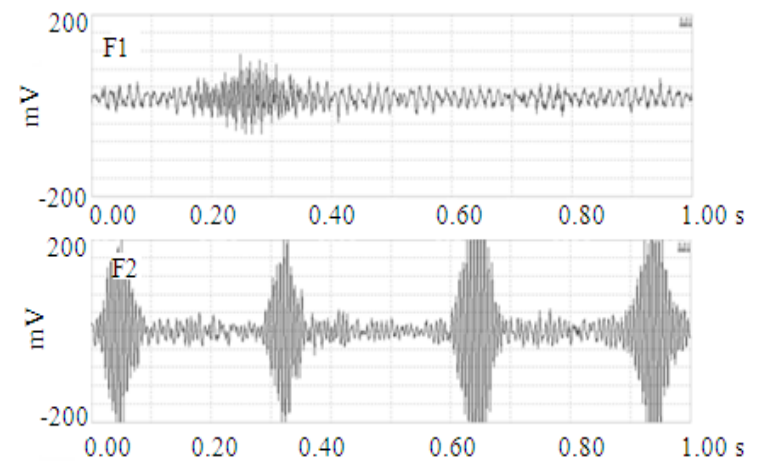

Fig. 2: Sample oscillograms of pulse trains for substrate-borne songs of Females (F1-2) of E. servus

Table 1: Mean \pm SD of Dominant Frequency (DF), Duration (D) and Repetition Time (RT) of substrate-borne songs of Females (F1-2) and Males (M1-4) of E. servus. Means in a column followed by the same letters are not significantly different

\begin{tabular}{llll}
\hline Song type & DF $(\mathrm{Hz})$ & $\mathrm{D}(\mathrm{s})$ & $\mathrm{RT}(\mathrm{s})$ \\
\hline F1 $(\mathrm{N}=6)$ & $184.850 \pm 30.566 \mathrm{a}$ & $0.230 \pm 0.190 \mathrm{abcde}$ & $3.327 \pm 0.705 \mathrm{a}$ \\
$\mathrm{F} 2(\mathrm{~N}=175)$ & $129.678 \pm 21.220 \mathrm{~b}$ & $0.196 \pm 0.061 \mathrm{a}$ & $0.277 \pm 0.070 \mathrm{~b}$ \\
$\mathrm{M} 1(\mathrm{~N}=132)$ & $76.664 \pm 6.975 \mathrm{c}$ & $0.328 \pm 0.058 \mathrm{~b}$ & $0.687 \pm 0.166 \mathrm{c}$ \\
M2 $(\mathrm{N}=65)$ & $105.383 \pm 3.307 \mathrm{~d}$ & $0.216 \pm 0.027 \mathrm{c}$ & $0.440 \pm 0.037 \mathrm{~d}$ \\
M3 $(\mathrm{N}=148)$ & $136.149 \pm 11.373 \mathrm{a}$ & $0.174 \pm 0.034 \mathrm{~d}$ & $0.294 \pm 0.033 \mathrm{e}$ \\
M4 $(\mathrm{N}=5)$ & $132.900 \pm 1.418 \mathrm{ab}$ & $0.452 \pm 0.055 \mathrm{e}$ & $0.800 \pm 0.178 \mathrm{~cd}$ \\
\hline
\end{tabular}




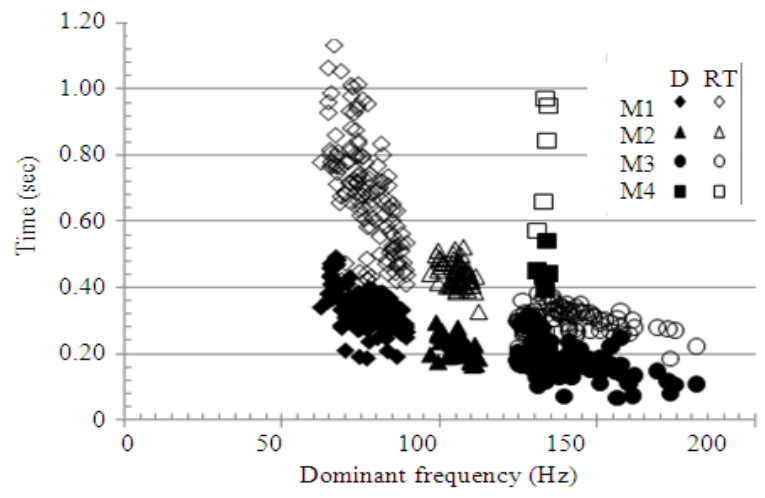

Fig. 3: Dominant frequency, Duration (D) and Repetition Time (RT) for classifications of substrate-borne songs of Males (M1-4) of E. servus

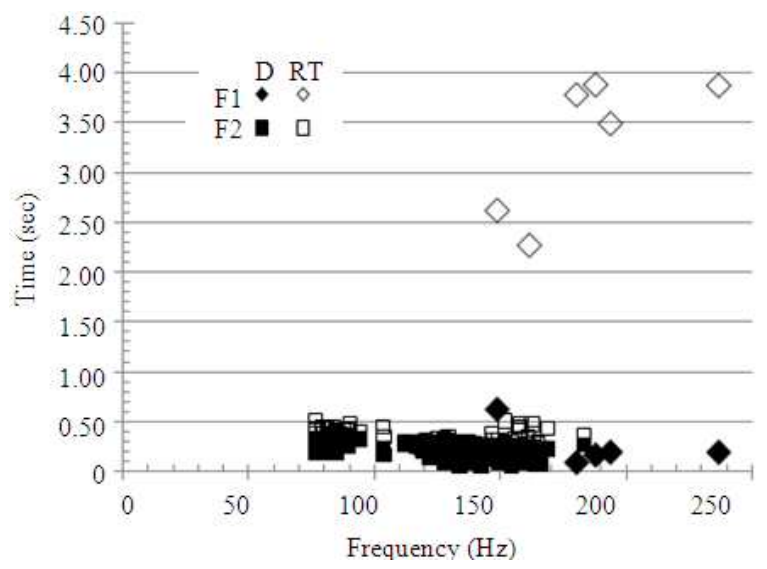

Fig. 4: Dominant frequency, Duration (D) and Repetition Time (RT) for classifications of substrate-borne songs of Females (F1-2) of E. servus

\section{DISCUSSION}

It can be concluded that E. servus has at least two and four distinct songs for females and males, respectively. The songs differ in mean dominant frequency, duration and/or repetition time. The number of distinct songs is the same as that reported previously for the congeneric species E. conspersus (McBrien and Millar, 2003) and E. heros (Blassioli Moraes et al., 2005), but songs of the three species are different in that, for example, F1 of E. servus is higher in mean dominant frequency and F2 is shorter in mean repetition time than was reported for either female song of E. conspersus (McBrien and Millar, 2003) or E. heros (Blassioli Moraes et al., 2005) and M1 is lower in mean dominant frequency than any of the 4 male songs of E. conspersus (McBrien and Millar, 2003) or E. heros (Blassioli Moraes et al., 2005). F2 and M3 of E. servus, FS-2 and MS3 of E. conspersus and FS-1 and MS-1 of E. heros, however, all occur when a male and female are together and one is emitted while the other member of the pair is silent (McBrien and Millar, 2003; Blassioli Moraes et al., 2005).

Comparisons between characteristics of songs of $E$. servus and those of $N$. viridula from Florida (Cokl et al., 2000) demonstrated species-specific differences between songs associated with these apparent shortrange communication mechanisms. Mean duration of F1did not differ significantly from that of the broadband female calling song $(\mathrm{t}=-1.314$; $\mathrm{df}=5.85 ; \mathrm{p}=$ $0.246)$, narrow-band male calling song $(\mathrm{t}=-1.817$; $\mathrm{df}$ $=5.84 ; \mathrm{p}=0.129)$, broad-band male calling $\operatorname{song}(\mathrm{t}=$ $-2.037 ; \mathrm{df}=5.84 ; \mathrm{p}=0.097)$, nor male rivalry song $(\mathrm{t}=$ $0.013 ; \mathrm{df}=5.88 ; \mathrm{p}=0.990)$ of $N$. viridula. Mean repetition time of $\mathrm{F} 1$ did not significantly differ from the narrow-band female calling song $(\mathrm{t}=1.884$; $\mathrm{df}=$ $41 ; \mathrm{p}=0.067)$ and mean repetition time of $\mathrm{M} 1 \mathrm{did}$ not differ significantly from the male rivalry song $(\mathrm{t}=$ 0.407; df $=209 ; \mathrm{p}=0.684$ ). All other mean durations and repetition times for all other songs were significantly different $(\mathrm{p}<0.05)$. Because the acoustic repertoire of this species is significantly different from other species found in the southeastern United States, it would be necessary to include these parameters with those of other species of stink bug to fully detect these insects.

\section{CONCLUSION}

In conclusion, detection of pentatomidae pests by their substrate-borne vibrational signals must include the parameters of each unique song of each species of stink bug to be detected, including those of the two female and four male songs of E. servus. The characterization of these songs will allow for the development of a monitoring system in the field using strategically placed accelerometers to detect stink bug vibrational communication and thus provide a density map of the location of these pests.

\section{ACKNOWLEDGEMENT}

Technical Contribution No. 5552 of the Clemson University Experiment Station. This material is based upon work supported by CSREES/USDA, under project number SC-1700289. 


\section{REFERENCES}

Roach, S.H., 1988. Stink bugs in cotton and estimation of damage caused by their feeding on fruiting structures. Proceedings of the Beltwide Cotton Production Research Conferences, Jan. 3-8, National Cotton Council of America, New Orleans, Louisiana, United States of America, pp: 292-293. http://www.fao.org/agris/search/display.do?f=./198 9/v1517/US8867605.xml;US8867605

Turnipseed, S.G. and J.K. Greene, 1996. Strategies for managing stink bugs in transgenic BT cotton. Proceedings of the Beltwide Cotton Conference, (BCC'96), National Cotton Council of America, United States of America, pp: 935-936. http://www.fao.org/agris/search/display.do?f=./199 7/v2315/US9728700.xml;US9728700

Greene, J.K., S.G. Turnipseed, M.J. Sullivan and O.L. May, 2001. Treatment thresholds for stink bugs (Hemiptera: Pentatomidae) in cotton. J. Econ. Entomol., 94: 403-409. DOI: 10.1603/00220493(2001)094[0403:TTFSBH]2.0.CO;2

Wene, G.P. and L.W. Sheets, 1964. Notes on and control of stink bugs affecting cotton in Arizona. J. Econ. Entomol., 57: 60-62. http://esa.publisher.ingentaconnect.com/content/esa /jee/1964/00000057/00000001/art00024

Barbour, K.S., J.R. Bradley Jr. and J.S. Bachelor, 1988. Phytophagous stink bugs in North Carolina cotton: An evaluation of damage potential. Proceedings of the Beltwide Cotton Production Research Conferences, Jan. 3-8, National Cotton Council of America, New Orleans, Louisiana, United States of America, $\quad$ pp: 280-282. http://www.fao.org/agris/search/display.do?f=./198 9/v1517/US8867599.xml;US8867599

Williams, M.R., 2006. Cotton insect losses-2005. Proceedings of the Beltwide Cotton Conference, Jan. 3-6, National Cotton Council of America, San Antonio, Taxes, pp: 1151-1204. http://ncc.confex.com/ncc/2006/techprogram/P560 2.HTM

Harris, V.E., J.W. Todd, J.C. Webb and J.C. Benner, 1982. Acoustical and behavioral analysis of the songs of the southern green stink bug, Nezara viridula. Ann. Entomol. Soc. Am., 75: 234-249. http://esa.publisher.ingentaconnect.com/content/esa /aesa/1982/00000075/00000003/art00004
Cokl, A., H.L. McBrien and J.G. Millar, 2001. Comparison of substrate-borne vibrational signals of two stink bug species, Acrosternum hilare and Nezara viridula (Heteroptera: Pentatomidae). Ann. Entomol. Soc. Am., 94: 471-479. DOI: 10.1603/00138746(2001)094[0471:COSBVS]2.0.CO;2

Bundy, C.S. and R.M. McPherson, 2000. Dynamics and seasonal abundance of stink bugs (Heteroptera: Pentatomidae) in a cotton-soybean ecosystem. J. Econ. Entomol., 93: 697-706. DOI: 10.1603/00220493(2000)093[0697:DASAOS]2.0.CO;2

Cokl, A. and M. Virant-Doberlet, 2003. Communication with substrate-borne signals in small plant-dwelling insects. Ann. Rev. Entomol., 48: 29-50.

DOI: 10.1146/annurev.ento.48.091801.112605

Cokl, A., 2008. Stink bug interaction with host plants during communication. J. Insect Physiol., 54: 1113-1124. DOI: 10.1016/j.insphys.2008.06.004

McBrien, H.L. and J.G. Millar, 2003. Substrate-borne vibrational signals of the consperse stink bug (Hemiptera: Pentatomidae). Can. Entomol., 135: 555-568.

http://direct.bl.uk/bld/PlaceOrder.do?UIN=144333 $377 \&$ ETOC $=$ RN\& from $=$ searchengine

Blassioli Moraes, M.C., R.A. Laumann, A. Cokl and M. Borges, 2005. Vibratory signals of four Neotropical stink bug species. Physiol. Entomol., 30: $\quad 175-188$. DOI: $\quad 10.1111 / \mathrm{j} .1365-$ 3032.2005.00446.x

Harris, V.E. and J.W. Todd, 1981. Rearing the southern green stink bug, Nezara viridula, with relevant aspects of its biology. J. Georgia Entomol. Soc., 16: 203-210.

http://www.cababstractsplus.org/abstracts/Abstract. aspx?AcNo=19810586444

Cokl, A., M. Virant-Doberlet and N. Stritih, 2000. The structure and function of songs emitted by southern green stink bugs from Brazil, Florida, Italy and Slovenia. Physiol. Entomol., 25: 196-205. DOI: 10.1046/j.1365-3032.2000.00187.x 